American Journal of Applied Sciences 6 (5): 869-875, 2009

ISSN 1546-9239

(C) 2009 Science Publications

\title{
Bio-oils from Pyrolysis of Oil Palm Empty Fruit Bunches
}

\author{
${ }^{1}$ Mohamad Azri Sukiran, ${ }^{1}$ Chow Mee Chin and ${ }^{2}$ Nor Kartini Abu Bakar \\ ${ }^{1}$ Malaysian Palm Oil Board, No. 6, Persiaran Institusi, Bandar Baru Bangi, \\ 43000 Kajang, Selangor, Malaysia \\ ${ }^{2}$ Department of Chemistry, University of Malaya, 50603 Kuala Lumpur, Malaysia
}

\begin{abstract}
Problem Statement: The palm oil industry generates an abundance of oil palm biomass such as the mesocarp fibre, shell, empty fruit bunch (EFB), frond, trunk and palm oil mill effluent (POME). For 80 million tonnes of fresh fruit bunch (FFB) processed last year, the amount of oil palm biomass was more than 25 million tones. The objectives of this study were to: (i) Determine the effect of various pyrolysis parameters on product yields and (ii) Characterise liquid product obtained under different condition. Approach: In this study, pyrolysis of oil palm Empty Fruit Bunches (EFB) was investigated using quartz fluidized fixed bed reactor. The effects of pyrolysis temperatures, particle sizes and heating rates on the yield of the products were investigated. The temperature of pyrolysis and heating rate were varied in the range $300-700{ }^{\circ} \mathrm{C}$ and $10-100{ }^{\circ} \mathrm{C} \min ^{1}$ respectively. The particle size was varied in the range of $<90,91-106,107-125$ and 126-250 $\mu \mathrm{m}$. The elemental analysis and calorific value of the bio-oil were determined. The chemical composition of the oil was investigated using chromatographic and spectroscopic techniques. Results: Under the experimental conditions, the maximum bio-oil yield was $42.28 \%$ obtained at $500{ }^{\circ} \mathrm{C}$, with a heating rate of $100{ }^{\circ} \mathrm{C} \mathrm{min}^{-1}$ and particle size of 91-106 $\mu \mathrm{m}$. The calorific values of bio-oil ranged from $20-21 \mathrm{MJ} \mathrm{kg}^{-1}$. A great range of functional groups of phenol, alcohols, ketones, aldehydes and carboxylic acids were indicated in FTIR spectrum. Conclusion: The chemical characterisation results showed that the bio-oil obtained from oil palm EFB maybe a potentially valuable source as fuel or chemical feedstocks.
\end{abstract}

Key words: Empty Fruit Bunches (EFB), palm oil, pyrolysis and bio-oil

\section{INTRODUCTION}

Oil palm (Elaeis guineensis) was introduced in Peninsular Malaysia in 1870 and was commercially exploited in the 1900s. Today, oil palm is the most economically attractive crop in Malaysia. With a total planted area of 4.2 million hectares, it plays an important role in the socio-economy and well being of the country.

Biomass is mainly derived from the agriculture or forestry sector. Today, various forms of biomass are consumed all over the world for energy generation. Biomass provides a clean, renewable energy source that could dramatically improve the environment, economy and energy security. The use of these materials will depend on safe state of the art, economic and technologies that are used to transform them into manageable products ${ }^{[17]}$. One of the indigenous biomass resources in Southeast Asia is derived from the oil palm. The oil palm empty fruit bunches, fiber and shell which are generally considered as 'waste' are generated every year in Malaysian, with an annual increment of $5 \%{ }^{[22]}$. While much research has been carried out to utilise them for the manufacture of value added products, its commercial utilization is not widespread. As fossil fuel gets depleted, exploitation of biomass as renewable materials by conversion to a transportable form of green fuel is being fervently researched. These include pyrolysis ${ }^{[20,23]}$, gasification $^{[6,24]}$ and liquefaction ${ }^{[2,21]}$.

Pyrolysis is one of the most promising technologies of biomass utilization ${ }^{[3,10]}$, which converts the biomass to bio-oil, char and gases depending on the pyrolysis conditions. Pyrolysis may be described as a thermal degradation of materials in the complete absence or inadequate presence of oxygen.

Uzun et al. ${ }^{[19]}$ investigated the effect of temperature, nitrogen flow rates, heating rates and particle sizes, influencing pyrolysis product yields from soybean cake. Ozcimen et al. ${ }^{[14]}$ pyrolysed rapeseed cake for bio-oil and bio-char and identified the various characteristics of bio-oil and bio-char acquired under static atmospheric conditions.

Onay et al. ${ }^{[13]}$ pyrolysed rapeseed in a free fall reactor at atmospheric pressure under nitrogen atmosphere. The effects of final temperature, particle

Corresponding Author: Mohamad Azri Sukiran, Malaysian Palm Oil Board, No. 6, Persiaran Institusi, Bandar Baru Bangi, 43000 Kajang, Selangor, Malaysia 
size and sweep gas flow rate on the yields of products were investigated. Tsai et al. ${ }^{[18]}$ fast pyrolysed rice straw, sugarcane bagasse and coconut shell in an externally heated fixed-bed reactor. Valuable products were obtained. The effect of process parameters such as pyrolysis temperature, heating rate and holding time on the yields of pyrolysis products and their chemical composition were also investigated.

In this study, pulverised empty fruit bunches was pyrolysed under different conditions in a fluidised fixed-bed reactor and the products obtained were characterised.

\section{MATERIALS AND METHODS}

Raw material: An empty fruit bunch of about $5 \mathrm{~kg}$ was collected from a palm oil mill located in Padang Jawa, Klang. The bunch was dried at $100 \pm 5{ }^{\circ} \mathrm{C}$ and cut into smaller pieces. It was then milled, sieved and separated in fractions using the test sieve shaker, Endecotts EFL 2000 . The separated portion level particle size was $<90$ $\mu \mathrm{m}, 91-106 \mu \mathrm{m}, 107-125 \mu \mathrm{m}$ and 126-250 $\mu \mathrm{m}$.

Characterisation of the EFB includes proximate analysis, calorific value and elemental analysis. The proximate analysis was used to determine the moisture content, volatile matter, fixed carbon and ash content in EFB. The calorific value of the EFB was determined using a bomb calorimeter, Leco AC-350. The test procedure consists of EFB weighing (0.5-1.0 g), installing a fuse and charging the bomb with oxygen to approximately $200 \mathrm{psi}$. The carbon, hydrogen and nitrogen contents of EFB were determined using a Euro EA3000 series, Elemental Analyzer.

Pyrolysis experiments: Pyrolysis of the oil palm empty fruit bunches was carried out using a quartz fluidised fixed bed reactor. A weighed sample of pulverised biomass was introduced into the reactor. The reactor with a length $135 \mathrm{mM}$ and an inner diameter of $40 \mathrm{mM}$ was introduced into the electric furnace. The temperature of the reactor was determined by inserting a thermocouple as near the upper fritz as possible.

The whole experimental rig that consists of the volatiles and gas collection system is as illustrated in Fig. 1.

Fluidised bed was generated using Argon at rate 1.5 litre per min, on $160 \mathrm{~g}$ zircon sand of $180-250 \mu \mathrm{m}$. For every experiment, $2 \mathrm{~g}$ of EFB feedstock was introduced into the bed of zircon sand.

Three series of experiments were carried out. The first was to determine the effect of the final pyrolysis temperature of $300,400,500,600$ or $700{ }^{\circ} \mathrm{C}$ on pyrolysis products. The heating rate was maintained at $30^{\circ} \mathrm{C}$ $\min ^{-1}$ and particle size of empty fruit bunches used was 91-106 $\mu \mathrm{m}$.

The second series of experiments was to determine the effect of particle size on the pyrolysis products. Four different particle size ranges of $<90 \mu \mathrm{m}, 91-106$ $\mu \mathrm{m}, 107-125 \mu \mathrm{m}$ and $126-250 \mu \mathrm{m}$ were pyrolysed at heating rate of $30{ }^{\circ} \mathrm{C} \mathrm{min}^{-1}$. Final temperature was maintained at $500{ }^{\circ} \mathrm{C}$.

The third series of experiments was to determine the effect of heating rate on the pyrolysis products. Heating rates of $10,30,50$ and $100{ }^{\circ} \mathrm{C} \min ^{-1}$ were studied. The final pyrolysis temperature was maintained at $500{ }^{\circ} \mathrm{C}$ and particle size of empty fruit bunches was 91-106 $\mu \mathrm{m}$.

Bio-oils characterisation: The water content of the bio-oils product was measured using Karl Fischer Titration, 784 KFP (Titrino, Metrohm). The bio-oils to be analysed was titrated with standard Karl Fischer reagent to an electrometric end point.

The carbon, hydrogen and nitrogen contents of biooils were determined using a Euro EA3000 series, Elemental Analyzer. Identified by reference to standard calibration and percent element of samples were determined by peak areas.

The calorific value of the bio-oils was determined by using a bomb calorimeter, Leco AC-350. The $\mathrm{pH}$ of the bio-oils measured by a $\mathrm{pH}$ meter from Eutech Instruments, type of $\mathrm{pH}$ Tutor.

The density of bio-oils was determined using Digital Density Meter, type DE 40 (Mettler, Toledo). The total acid value determined by using Pontentiometric Titration, 702 SM (Titrino, Metrohm). The acid value is expressed as the amount (in miligramms) potassium hydroxide required to neutralize one gram of the bio-oils $\left(\mathrm{mgKOHg}^{-1}\right)$.

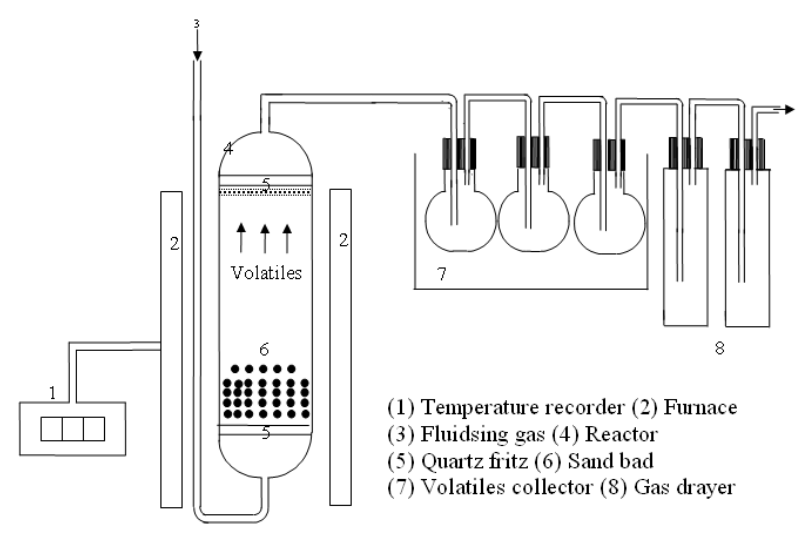

Fig. 1: Schematic diagram of the pyrolysis system 
The total ash analysis was based on ASTM D 482. The sample contained in a suitable vessel was ignited and allowed to burn until only ash and carbon remained. The carbonaceous residue is reduced to an ash by heating in a furnace at $775{ }^{\circ} \mathrm{C}$ with a heating time of $20 \mathrm{~min}$, followed by cooling and weighing.

Functional groups analysis of the bio-oils was detected using Fourier Transform Infra-Red (FTIR) spectroscopy, Magna-IR550 (Nicolet, Madison). A small amount of the bio-oils was mounted on a potassium bromide $(\mathrm{KBr})$ disc that had been previously scanned as a background.

The Gas Chromatography/Mass Spectroscopy (GC/MS) analysis of the bio-oils was performed with a Agilent Technology 6890-N equipped with a SGE.

BPX5 column and MSD detector, using 30x250x0.25 $\mathrm{mM}$ capillary column. The starting temperature of the oven was $35{ }^{\circ} \mathrm{C}$. It was held for $2 \mathrm{~min}$ before the temperature was increased to $250{ }^{\circ} \mathrm{C}$ at the rate of 20 ${ }^{\circ} \mathrm{C} \min ^{-1}$ and held at its temperature for $20 \mathrm{~min}$. The injector port temperature and the detector temperature was set at $280{ }^{\circ} \mathrm{C}$.

\section{RESULTS}

Raw material: Empty fruit bunches a by-product of a palm oil mill were used in the work. The results of proximate analysis, elemental analysis and calorific value of palm oil empty fruit bunches are listed in Table 1. The calorific value of empty fruit bunches was 17.08 $\mathrm{MJ} \mathrm{kg}^{-1}$ generally which is typical for biomass is higher than the energy content of olive-oil residue $16.40 \mathrm{MJ}$ $\mathrm{kg}^{-1[20]}$.

The volatiles, fixed carbon and ash content of empty fruit bunches are $81.9 \mathrm{wt} \%, 12.6 \mathrm{wt} \%$ and 3.1 $\mathrm{wt} \%$, respectively. The elemental analysis provides the chemical composition of the EFB in elemental terms and is used to determine the combustion air requirements, flue losses and likely emission levels. From this analysis, it was found that the EFB contained $53.78 \mathrm{wt} \%$ of Carbon, $4.37 \mathrm{wt} \%$ of Hydrogen, 41.50 wt $\%$ of Oxygen and 0.35 wt $\%$ of Nitrogen. The H/C and $\mathrm{O} / \mathrm{C}$ ratios of $\mathrm{EFB}$ were 0.98 and 0.58 , respectively. If considering only the main elements $(\mathrm{C}, \mathrm{H}, \mathrm{O}, \mathrm{N})$, the molecular formula of the studied samples based on one $\mathrm{C}$ atom can be written as $\mathrm{CH}_{0.98} \mathrm{O}_{0.58} \mathrm{~N}_{0.02}$.

\section{Pyrolysis experiments:}

Effect of temperature: The effect of final pyrolysis temperature on product yields is shown in Fig. 2. At the lowest pyrolysis temperature of $300{ }^{\circ} \mathrm{C}$, decomposition was insignificant as char was the major product. At 500 ${ }^{\circ} \mathrm{C}$, the amount of condensed liquid product (bio-oil) increased to a maximum value in the range of 33-35 wt $\%$ of feedstock. At higher pyrolysis temperatures of $600{ }^{\circ} \mathrm{C}$ and $700{ }^{\circ} \mathrm{C}$, the bio-oil decreased to $30-32 \mathrm{wt} \%$ of feedstock. Yorgun et al. ${ }^{[23]}$ and Acikgoz et al..$^{[1]}$ studies on pyrolysis of sunflower oil cake and linseed respectively, indicated the same trend. Gas yield was obtained at the range $31-46 \mathrm{wt} \%$ of feedstock over the temperature range of $300{ }^{\circ} \mathrm{C}$ to $700{ }^{\circ} \mathrm{C}$. The maximum liquid product yield obtained was $35 \mathrm{wt} \%$ of feedstock at the pyrolysis temperature of $500{ }^{\circ} \mathrm{C}$.

Effect of particle size: The effect of particle size on the product yields is given in Fig. 3 at a pyrolysis temperature of $500{ }^{\circ} \mathrm{C}$ at heating rate of $30{ }^{\circ} \mathrm{C} \mathrm{min}{ }^{-1}$. Biomass of particle size of $<91 \mu \mathrm{m}$ produced a bio-oil yield of $33 \mathrm{wt} \%$ of feedstock was only about $2 \mathrm{wt} \%$ higher than that of the highest particle size with a char yield of $28 \mathrm{wt} \%$ of feedstock and gas yield of $39 \%$ wt $\%$ of feedstock. Larger particle size of $126-250 \mu \mathrm{m}$ produced a bio-oil yield of $31 \mathrm{wt} \%$ of feedstock with a char yield of 28 wt $\%$ of feedstock and gas yield of 41 wt $\%$ of feedstock. A maximum bio-oil yield was obtained with particle size of 91-106 $\mu \mathrm{m}$ about a 35 wt $\%$ of feedstock with a char yield $25 \mathrm{wt} \%$ of feedstock.

Table 1: Main characteristics of the treated oil palm EFB

\begin{tabular}{lc}
\hline Characteristics & EFB \\
\hline Proximate analysis (wt\%) & \\
Volatiles & 81.90 \\
Fixed Carbon & 12.60 \\
Ash & 3.10 \\
Moisture & 2.40 \\
Ultimate analysis (wt $\%)$ & \\
Carbon & 53.78 \\
Hydrogen & 4.37 \\
Nitrogen & 0.35 \\
Oxygen & 41.50 \\
H/C & 0.98 \\
O/C & 0.58 \\
Empirical formula & $\mathrm{CH}_{0.98} \mathrm{O}_{0.58} \mathrm{~N}_{0.01}$ \\
Calorific value $\left(\mathrm{MJ} \mathrm{kg}^{-1}\right)$ & 17.08 \\
\hline${ }^{\mathrm{a}}$ By difference &
\end{tabular}

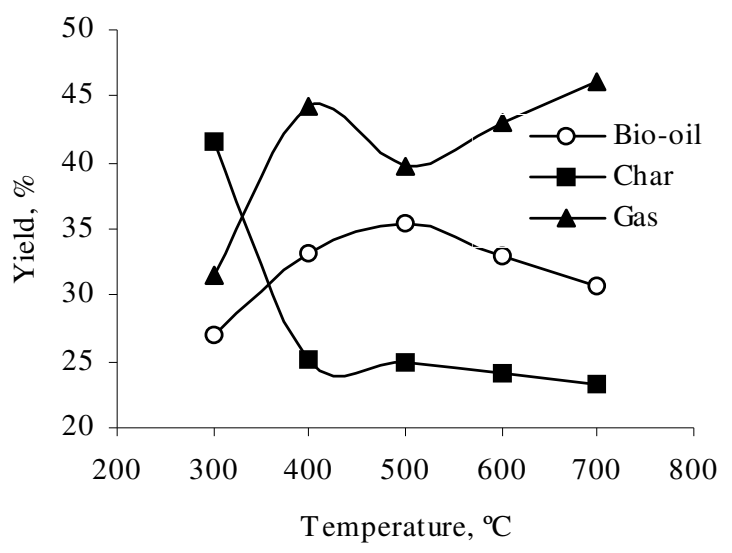

Fig. 2: Yield of pyrolysis products at various final pyrolysis temperatures with a heating rate of 30 ${ }^{\circ} \mathrm{C}$ min $^{-1}$ and particle size of $91-106 \mu \mathrm{m}$ 
Am. J. Applied Sci., 6 (5): 869-875, 2009

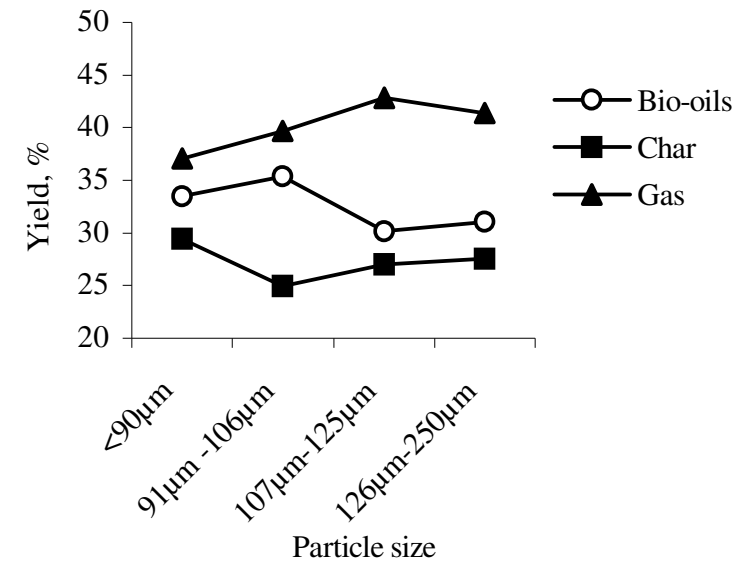

Fig. 3: Yield of pyrolysis products at various particle size with a final temperature of $500^{\circ} \mathrm{C}$ and heating rate of $30^{\circ} \mathrm{C} \mathrm{min}^{-1}$

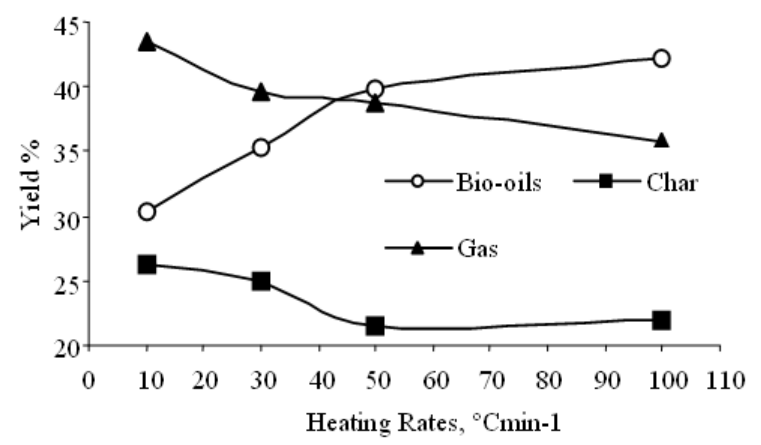

Fig. 4: Yield of pyrolysis products at various heating rate with a final temperature of $500{ }^{\circ} \mathrm{C}$ and particle size of $91-106 \mu \mathrm{m}$

Effect of heating rate: The effect of heating rate on product yields is as shown in Fig. 4. The bio-oil yield reached a maximum value of $42 \mathrm{wt} \%$ of feedstock with a highest heating rate of $100{ }^{\circ} \mathrm{C} \mathrm{min}^{-1}$. The lowest biooil yields were obtained at the heating rate $10{ }^{\circ} \mathrm{C} \mathrm{min}{ }^{-1}$ (30 wt $\%$ of feedstock). In this study, the highest char yield was obtained at the heating rate of $10^{\circ} \mathrm{C} \mathrm{min}$ (26 wt\% of feedstock). The lowest char yield was obtained at the heating rate of $50{ }^{\circ} \mathrm{C} \min ^{-1}$. (21 wt $\%$ of feedstock). Gas yield was obtained at the range 35-43 $\mathrm{wt} \%$ of feedstock over the temperature range of $10-100$ ${ }^{\circ} \mathrm{C} \min ^{-1}$.

Bio-oils characterisation: The bio-oils obtained at temperature of 400,500 and $600{ }^{\circ} \mathrm{C}$ with heating rate of $30{ }^{\circ} \mathrm{C} \mathrm{min}^{-1}$ and particle size of $91-106 \mu \mathrm{m}$ was characterised with respect to liquid fuel
Table 2: Characteristics of bio-oil obtained at heating rate of $30{ }^{\circ} \mathrm{C}$ $\min ^{-1}$ and particle size of $91-106 \mu \mathrm{m}$

\begin{tabular}{|c|c|c|c|c|}
\hline \multirow[b]{2}{*}{ Properties } & \multicolumn{4}{|c|}{ Temperature $\left({ }^{\circ} \mathrm{C}\right)$} \\
\hline & 400 & 500 & 600 & $\begin{array}{l}\text { Bio-oil from } \\
\text { rapeseed }^{\mathrm{a}}\end{array}$ \\
\hline $\begin{array}{l}\text { 1. Calorific Value } \\
(\mathrm{MJ} / \mathrm{kg})\end{array}$ & 20.23 & 21.41 & 21.17 & 38.40 \\
\hline 2. Total Ash, \% & 0.49 & 0.65 & 0.37 & - \\
\hline 3. $\mathrm{pH}$ & 3.40 & 3.00 & 3.00 & - \\
\hline 4. Moisture (\%) & 17.89 & 18.74 & 18.21 & None \\
\hline $\begin{array}{l}\text { 5. Total Acid (mg, } \\
\left.\text { KOH.g }{ }^{-1}\right)\end{array}$ & 81.81 & 75.62 & 67.75 & - \\
\hline $\begin{array}{l}\text { 6. Density }\left(\mathrm{g} / \mathrm{cm}^{3}\right) \\
\text { 7. Ultimate analysis } \\
\text { (w/w\%) }\end{array}$ & 1.00 & 0.90 & 0.99 & 0.92 \\
\hline Carbon & 35.29 & 49.80 & 53.75 & 74.04 \\
\hline Hydrogen & 6.67 & 7.98 & 8.81 & 10.29 \\
\hline Oxygen & 57.02 & 40.29 & 36.04 & 11.70 \\
\hline Nitrogen & 1.02 & 1.93 & 1.40 & 3.97 \\
\hline $\mathrm{H} / \mathrm{C}$ molar ratio & 2.27 & 1.92 & 1.97 & 1.67 \\
\hline $\mathrm{O} / \mathrm{C}$ molar ratio & 1.21 & 0.61 & 0.50 & 0.12 \\
\hline Empirical formula & $\begin{array}{l}\mathrm{CH}_{2.27} \\
\mathrm{O}_{1.21} \mathrm{~N}_{0.02}\end{array}$ & $\begin{array}{l}\mathrm{CH}_{1.92} \\
\mathrm{O}_{0.61} \mathrm{~N}_{0.03}\end{array}$ & $\begin{array}{l}\mathrm{CH}_{1.97} \\
\mathrm{O}_{0.50} \mathrm{~N}_{0.02}\end{array}$ & $\begin{array}{l}\mathrm{CH}_{1.67} \\
\mathrm{O}_{0.12} \mathrm{~N}_{0.05}\end{array}$ \\
\hline
\end{tabular}

characteristics as shown in Table 2. The moisture content of bio-oils varied between 18 and $19 \%$ depending on the production condition. The $\mathrm{pH}$ value of the bio-oils varied between 3.0 and 3.4. The finding is in agreement with the same published data ${ }^{[3]}$ that is, bio-oil generally contained substantial amount of organic acids, mostly acetic acid and formic acids, which give the bio-oil its low $\mathrm{pH}(2-3)$. The acid values of the bio-oils vary between 68 and $82 \mathrm{mg}, \mathrm{KOH} \mathrm{g}^{-1}$.

The calorific values of bio-oils ranged from 20-21 $\mathrm{MJ} \mathrm{kg}^{-1}$, which is much lower than that of gasoline 47 MJ kg-1, diesel fuel $43 \mathrm{MJ} \mathrm{kg}^{-1}$ or petroleum $42 \mathrm{MJ}$ $\mathrm{kg}^{-1[16]}$. The ash content in the bio-oils varied from 0.37 to $0.65 \%$. Ash can result from oil or water-soluble metallic compounds or from extraneous solids such as dirt and rust. The density of bio-oils ranged between 0.90 and $1.00 \mathrm{~g} \mathrm{~cm}^{-3}$. Density is a fundamental physical property that can be used in conjunction with other properties to characterize of bio-oil products.

The elemental compositions analysis, $\mathrm{H} / \mathrm{C}$ molar ratio, $\mathrm{O} / \mathrm{C}$ molar ratio and empirical formula of the biooils are also shown in Table 2. The IR absorbances of the bio-oil are given in Fig. 5. A great range of functional groups of phenol, alcohols, ketones, aldehydes and carboxylic acids were indicated.

GC-MS analysis was carried out in order to get an idea of the nature and type of organic compounds in the pyrolysis liquid products. Table 3 lists the possible compounds identified by the MS search libraries (Wiley7n.L and NIST98.L) of the bio-oil. The highest percentage of area was phenol at $18.10 \%$. 


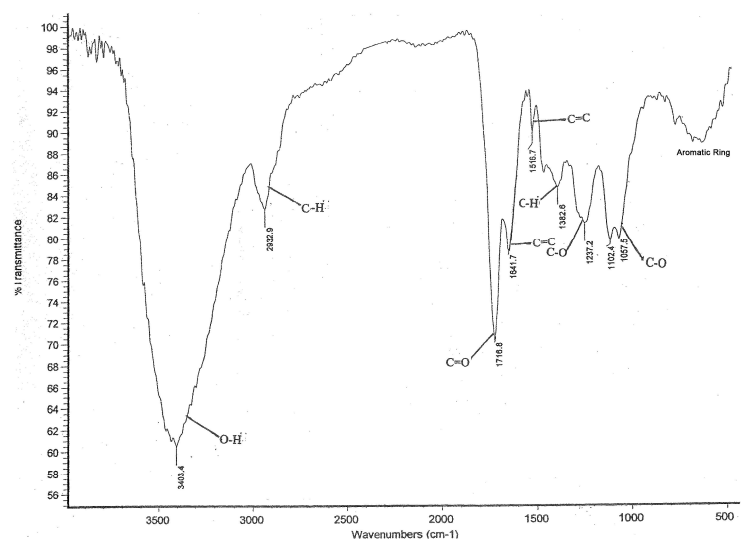

Fig. 5: Infrared spectra of the bio-oil obtained at temperature of $500^{\circ} \mathrm{C}$ heating rate of $30{ }^{\circ} \mathrm{C}$ $\min ^{-1}$ and particle size of $91-106 \mu \mathrm{m}$

Table 3: Chemical compounds of bio-oil* according to the GC/MS analysis

\begin{tabular}{lll}
\hline Peak no. & Chemical compound identification & Area $\%$ \\
\hline 1 & Furan, 2,5-dimethyl & 7.38 \\
2 & 2-Cyclopentene-1-one, 2-methyl & 2.20 \\
3 & 2H-Pyran, 3,4-dihydro & 2.99 \\
4 & Cyclopentanone, 2-methyl & 7.15 \\
5 & Phenol & 18.10 \\
6 & Furantetracarboxylic acid & 3.52 \\
7 & Phenol, 3-methyl & 1.98 \\
8 & Phenol, 4-methyl & 2.69 \\
9 & Phenol, 2-methoxy & 4.46 \\
10 & Phenol, 2,6-dimethoxy & 6.14 \\
11 & 2-Pentyn-1-ol & 4.08 \\
\hline *Obtained at temperature of $500^{\circ} \mathrm{C}$ heating rate of $30^{\circ} \mathrm{C} \mathrm{min}^{-1}$ and \\
particle size of 91-106 $\mu \mathrm{m}$
\end{tabular}

\section{DISCUSSION}

The higher treatment temperature has led to more bio-oil cracking resulting in higher gas yield and lower bio-oil yield ${ }^{[6,8,24]}$. Generally, the pyrolysis of the solid biomass conversion increased from a lower temperature to higher temperature ${ }^{[12,18]}$. The decrease in char yield with increasing temperature could either be due to greater primary decomposition of the EFB at higher temperatures or through secondary decomposition of the char residue. The secondary decomposition of the char at higher temperatures may also give noncondensable gaseous products, which would also contribute to the increase in gas yield with increasing pyrolysis temperatures ${ }^{[16]}$.

Encinar et $a .^{[7]}$ pyrolysed cardoon (Cynara cardunculus L.) with size ranged 0.43-2.00 $\mathrm{mm}$ hypothesized that an increase in particle size causes greater temperature gradients inside the particle so that at a given time the core temperature is lower than that of the surface, which possibly gives rise to an increase in the char yields and a decrease in liquids and gases. Particle size is known to influence pyrolysis products yield. If the particle size is sufficiently small it can be heated uniformly, as is consistent with earlier studies $^{[15]}$. However, in this work it was observed that particle size had no significant influence on the bio-oil.

The increase of the heating rate leads to increase yield of bio-oil. It was noted that, the higher heating rate, the lower effect of mass transport limitations ${ }^{[17]}$. The increase of the heating rate leads to decrease the char yield. This may be related to the rapid heating leads to a fast depolymerization of the solid material to primary volatiles, while at the lower heating rate dehydration to more stable anhydrocellulose is too slow and limited to occur ${ }^{[5]}$.

The moisture content (water) that is produced in the pyrolysis reaction together with any water contained from the biomass feedstock. The amount of water in the product also depends on the process parameters including the extent of secondary reaction or cracking and the temperature of the product gases leaving the liquid collection system. Water is important in many ways as; higher water content usually reduces viscosity, improves stability but reduces calorific value of biooils $^{[4]}$.

Hemicellulose from EFB contain glucuronic acids. This might be the reason for the higher amount of free acids in bio-oil which can cause polycondensation reactions of aldehydes and phenol. As $\mathrm{pH}$ measures the concentration of $\mathrm{H}_{3} \mathrm{O}^{+}$ions, $\mathrm{KOH}$ addition may lead to some saponification of esters and hence an unproportional consumption of alkali ${ }^{[4]}$. Obviously, there is no strong relationship between acid number and $\mathrm{pH}$.

For the bio-oils, high water content in combination with a high $\mathrm{O} / \mathrm{C}$ atomic ratio gives poor calorific values. On the other hand, at similar water content the calorific value of bio-oil is higher due to its lower $\mathrm{O} / \mathrm{C}$ atomic ratio $^{[11]}$. The significant decrease in the oxygen content of the bio-oil compared to the original feedstock $(\mathrm{CHON})$ is favourable, since the high oxygen content is not attractive for the production of transport fuel $^{[16]}$.

The FTIR analysis showed that the bio-oil composition was dominated by oxygenated species. The high oxygen content is reflected by the presence of mostly oxygenated fractions such as carboxyl and carbonyl groups produced by pyrolysis of the cellulose and phenolic and methoxy produced by pyrolysis of the lignin. The GC-MS results showed that the chemical compositions of the bio-oil which are very similar to the inclusion of a lot of aromatics and oxygenated 
compounds such as carboxylic acids, phenols, ketones and aldehydes. The presence of these aromatic and oxygenated compounds was attributed to its biopolymer textures such as cellulose and hemicellulose ${ }^{[18]}$.

\section{CONCLUSION}

In this study, pyrolysis experiments of oil palm empty fruit bunches were performed in a fludised fixedbed reactor. The highest bio-oil yield of $42 \%$ was obtained at an optimum pyrolysis temperature of 500 ${ }^{\circ} \mathrm{C}$ with particle size of 91-106 $\mu \mathrm{m}$ and the heating rate of $100^{\circ} \mathrm{C} \mathrm{min}^{-1}$. The higher treatment temperature has led to lower bio-oil yields and higher quality liquid fuels. The highest calorific value of the bio-oil obtained was $21.41 \mathrm{MJ} \mathrm{kg}^{-1}$.

\section{ACKNOWLEDGEMENT}

The financial support for research and equipment from the Malaysian Palm Oil Board (MPOB) and University of Malaya is acknowledged. We also grateful to all staff Energy and Environment Unit, MPOB for their valuable assistance with the experiments. The permission and technical assistance of Dr. Chun-Zhu Li of Monash University, Chemical Engineering Department to set-up the experimental pyrolysis rig is much appreciated without which this study would not have been possible.

\section{REFERENCES}

1. Acikgoz, C. and O.M. Kockar, 2007. Flash pyrolysis of linseed (Linum usitatissimum L.) for production of liquid fuels. J. Anal. Appl. Pyrol., 78: 406-412. DOI: 10.1016/j.jaap.2006.10.007.

2. Arso, A. and M. Iino, 2007. Effect of amines added on Banko coal liquefaction. J. Fuel Process.Technol., 88: 813-816. DOI:10.1016/j.fuproc.2007.04.002.

3. Bridgwater, A.V., D. Meier and D. Radlein, 1999. An overview of fast pyrolysis of biomass. J. Organic Geochem., 30: 1479-1493. DOI: $10.1016 / \mathrm{S} 0146-6380(99) 00120-5$.

4. Bridgwater, A.V., 1997. Fast Pyrolysis of Biomass in Europe. In: Biomass Gasification and Pyrolysis: State of the Art and Future Prospects, Kaltschmitt, M. and A.V. Bridgwater, (Eds.). CPL Press, United Kingdom, pp: 53-67. ISBN: 1872691714.

5. Chen, G., Q. Yu and K. Sjostrom, 1997. Reactivity of char from pyrolysis of birch wood. J. Anal. Appl. Pyrol., 40-41: 491-499. DOI: 10.1016/S0165-2370(97)00014-4.
6. Chen, G., J. Andries, Z. Luo and H. Spliethoff, 2003. Biomass pyrolysis/gasification for product gas production: The overall investigation of parametric effects. J. Energ. Conver. Manage., 44: 1875-1884. DOI: 10.1016/S0196-8904(02)001887.

7. Encinar, J.M., J.F. Gonzalez and J. Gonzalez, 2000. Fixed-bed pyrolysis of Cynara cardunculus L. Product yields and compositions. J. Fuel Process. Technol., 68: 209-222. DOI: 10.1016/S0378-3820(00)00125-9.

8. Ji-Lu, Z., 2007. Bio-oil from fast pyrolysis of rice husk: Yields and related properties and improvement of the pyrolysis system. J. Anal. Appl. Pyrol., 80: 30-35. DOI: 10.1016/j.jaap.2006.12.030.

9. Karaosmanoglu, F., E. Tetik and E. Gollu, 1999. Biofuel production using slow pyrolysis of the straw and stalk of the repeseed plant. J. Fuel Process. Technol., 59: 1-12. DOI: 10.1016/S03783820(99)00004-1.

10. Kawser, J., J. Hayashi and C.Z. Li, 2004. Pyrolysis of a Victorian brown coal and gasification of nascent char in $\mathrm{CO}_{2}$ atmosphere in a wire-mesh reactor. J. Fuel, 83: 833-843. DOI: 10.1016/j.fuel.2003.09.017.

11. Meier, D. and B. Scholze, 1997. Fast Pyrolysis of Biomass in Europe. In: Biomass Gasification and Pyrolysis: State of the Art and Future Prospects, Kaltschmitt, M. and A.V. Bridgwater (Eds.). CPL Press, United Kingdom, pp: 431-440. ISBN: 1872691714.

12. Onay, O., S.H. Beis and O.M. Kockar, 2001. Fast pyrolysis of rape seed in a well-swept fixed-bed reactor. J. Anal. Appl. Pyrol., 58-59: 995-1007. DOI: 10.1016/S0165-2370(00)00133-9.

13. Onay, O. and O.M. Kockar, 2006. Pyrolysis of rapeseed in a free fall reactor for production of biooil. J. Fuel, 85: 1921-1928. DOI: 10.1016/j.fuel.2006.03.009.

14. Ozcimen, D. and F. Karaosmanoglu, 2004. Production and characterization of bio-oil and biochar from rapeseed cake. J. Renew. Energ., 29: 779-787. DOI: 10.1016/j.renene.2003.09.006.

15. Seebauer, V., J. Petek and G. Staudinger, 1997. Effects of particle size, heating rate and pressure on measurement of pyrolysis kinetics by thermogravimetric analysis. J. Fuel, 76: 1277-1282. DOI: 10.1016/S0016-2361(97)00106-3.

16. Sensoz, S., D. Angin and S. Yorgun, 2000. Influence of particle size on the pyrolysis of rapeseed (Brassica napus L.): fuel properties of bio-oil. J. Biomass and Bioenergy, 19: 271-279. DOI: 10.1016/S0961-9534(00)00041-6. 
17. Sensoz, S., 2003. Slow pyrolysis of wood barks from Pinus brutia Ten and product compositions. J. Biores. Technol., 89: 307-311. DOI: 10.1016/S0960-8524(03)00059-2.

18. Tsai, W.T., M.K. Lee and Y.M. Chang, 2006. Fast pyrolysis of rice straw, sugarcane bagasse and coconut shell in an induction-heating reactor. J. Anal. Appl. Pyrol., 76: 230-237. DOI: 10.1016/j.jaap.2005.11.007.

19. Uzun, B.B., A.E. Putun and E. Putun, 2006. Fast pyrolysis of soybean cake: Product yields and compositions. J. Biores. Technol., 97: 569-576. DOI: 10.1016/j.biortech.2005.03.026.

20. Uzun, B.B., A.E. Putun and E. Putun, 2007. Composition of products obtained via fast pyrolysis of olive-oil residue: Effect of pyrolysis temperature. J. Anal. Appl. Pyrol., 79: 147-153. DOI: 10.1016/j.jaap.2006.12.005.
21. Wang, G., W. Li, B. Li and H. Chen, 2007. Direct liquefaction of sawdust under syngas. J. Fuel, 86: 1587-1593. DOI: 10.1016/j.fuel.2006.11.010.

22. Yang, H., R. Yan, H. Chen, D.H. Lee, D.T. Liang and C. Zheng, 2006. Mechanism of palm oil waste pyrolysis in a packed bed. J. Energy Fuels, 20: 1321-1328. DOI: 10.1021/ef0600311.

23. Yorgun, S., S. Sensoz and O.M. Kockar, 2001. Flash pyrolysis of sunflower oil cake for production of liquid fuels. J. Anal. Appl. Pyrol., 63: 1-12. DOI: 10.1016/S0165-2370(00)00102-9.

24. Zanzi, R., K. Sjostrom and E. Bjornbom, 2002. Rapid pyrolysis of agricultural residues at high temperature. J. Biomass and Bioenergy, 23: 357366. DOI: 10.1016/S0961-9534(02)00061-2. 